\title{
Special issue in honour of Jenô Egerváry
}

\author{
T. Csendes • A. Galántai • L. Szeidl
}

Published online: 24 December 2009

(C) Springer-Verlag 2009

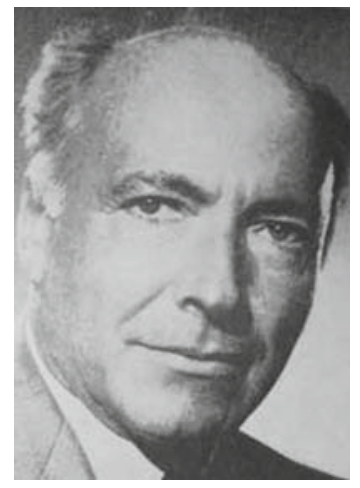

Jenő Egerváry (1891-1958) was a prominent scientist of pure and applied mathematics. He is best known for his contribution to the Hungarian method. However, his research activity included much more than that and he obtained many important and genuine results in other areas of mathematics and its applications. He was also an outstanding teacher and a key person of Hungarian applied mathematics until 1958, when he committed suicide. This was the aftermath of the 1956 revolution of Hungary with a harsh oppression. Not long after Egerváry's death, his research department was dissolved and by the early seventies he and his results were rarely mentioned in mathematical circles apart from his relation to the Hungarian method. At the end of the eighties his linear algebra related research came into light due to its connection

\footnotetext{
T. Csendes $(\varangle)$

University of Szeged, Szeged, Hungary

e-mail: csendes@inf.u-szeged.hu
}

A. Galántai · L. Szeidl

Budapest Tech, Budapest, Hungary 
with the ABS and other conjugate direction methods used in optimization algorithms. In 1999, the Bergamo University of Italy issued an Egerváry prize to Zhang Liwei of Dalien University of China. The Hungarian Operations Research Society was founded in 1990. It was one of HORS' principal aims to reach a higher level recognition of Egerváry and applied mathematics as well. The society organized a special memorial session for Egerváry on the 25th Conference of HORS and established the Egerváry medal for lifetime OR achievements in 2004. The first recipients of the Egerváry medal were András Prékopa, Emil Klafszky, Béla Martos, Pál Rózsa, György Meszéna, and József Kolumbán. Due to the efforts of HORS and former students of Egerváry, a statue of Egerváry was erected in the campus of the Technical University of Budapest in 2006. In 2007 Profs. Emilio Spedicato and Tamás Rapcsák proposed a memorial celebration of Egerváry on the occasion of the 50th anniversary of his death. Two such parallel events took place. The first one was organized as a special section of the 39th Annual Conference of the Italian Operational Research Society held in Ischia, September 7-11, 2008. The lectures were held by Profs. Silvano Martello, Aurél Galántai, and Emilio Sedicato. The second event took place as a special memorial workshop organized by the Operations Research Committee of the Hungarian Academy of Sciences and by the Hungarian Operations Research Society in Budapest Tech (Budapest) on the 12th December, 2008. The latter event consisted of 9 lectures that partly covered the scientific activity of Egerváry. It is worth noting that between 1918 and 1921 Egerváry was a teacher of the "Állami Felsőipariskola" (State Industrial College) which was one of the legal predecessors of the Budapest Tech college.

The present special issue of CEJOR is a selection of the lectures of the two parallel events. Each paper represents an active research area that is related to Egerváry's results. In addition to that, we include a paper of the late Prof. Rapcsák on Egerváry's life and work (Rapcsák 2010). The other papers focus on three different research areas.

The paper of Martello (2010) gives an interesting account of the several results that precede, follow or relate to the "Hungarian method". He points out connections with a recently discovered posthumous paper by Jacobi (1804-1851) and the Birkhoff-von Neumann theorem on doubly stochastic matrices. The paper also deals with a related combinatorial optimization problem defined in satellite communication and in scheduling theory.

The paper of Hujter (2010) gives a survey on some combinatorial results that are related to the famous Konig-Egerváry theorem.

Three papers are focusing on the linear algebra activity of Egerváry and its consequences in optimization as well.

The paper of Spedicato et al. (2010) gives a survey on the ABS methods for solving linear algebraic equations and their applications to optimization. The ABS methods are based on the rank reducing matrix update due to Egerváry and can be considered as the most fruitful extensions of such techniques.

The paper of Galántai (2010) gives a survey of the recent results on Egerváry's rank reduction algorithm and reports some applications in optimization algorithms.

Hegedús (2010) provides an interesting review on the Purcell method that was significantly improved by Egerváry in the context of his rank reduction procedure. Hegedús also shows various properties and connections of this method to Newton's multidimensional interpolation, ABS methods or the simplex updates. 
In the early period of his scientific carrier Egerváry developed quite a number of results on polynomials that are still of interest. The paper of Szabó (2010) introduces us to Egerváry's results on trinomial equations. The numerical examples show the sharpness of Egerváry's classical results while the whole material indicates further yet unexplored research possibilities on the subject.

\section{References}

Galántai A (2010) The rank reduction procedure of Egerváry. Cent Eur J Oper Res (this issue) Hegedús CJ (2010) Purcell's method, Egerváry and related results. Cent Eur J Oper Res (this issue)

Hujter M (2010) Some good characterization results relating to the Konig-Egerváry theorem. Cent Eur J Oper Res (this issue)

Martello S (2010) Jenő Egerváry: from the origins of the Hungarian algorithm to satellite communication. Cent Eur J Oper Res (this issue)

Rapcsák T (2010) The life and works of Jenő Egerváry (1891-1958). Cent Eur J Oper Res (this issue)

Spedicato E, Bodon E, Xia Z, Mahdavi-Amiri N (2010) ABS methods for continuous and integer linear equations and optimization. Cent Eur J Oper Res (this issue)

Szabó PG (2010) On the roots of the trinomial equation. Cent Eur J Oper Res (this issue) 